\title{
Production of an extracellular keratinase from Chryseobacterium sp. growing on raw feathers
}

\author{
Adriano Brandelli* \\ Laboratorio de Bioquímica e Microbiologia Aplicada \\ Departamento de Ciência de Alimentos, ICTA \\ Universidade Federal do Rio Grande do Sul \\ 91501-970 Porto Alegre, Brasil \\ Tel: 55133166249 \\ Fax: 55133167048 \\ E-mail: abrand@ufrgs.br \\ Alessandro Riffel \\ Laboratorio de Bioquímica e Microbiologia Aplicada \\ Departamento de Ciência de Alimentos, ICTA \\ Universidade Federal do Rio Grande do Sul \\ 91501-970 Porto Alegre, Brasil \\ Tel: 55133166249 \\ Fax: 55133167048 \\ E-mail: ariffel@esalq.usp.br
}

Financial support: This work was supported by CNPq and FAPERGS.

Keywords: bacteria, enzyme, keratin, protease.

The strain Chryseobacterium sp. kr6 shown to be useful for biotechnological purposes such as hydrolysis of poultry feathers and de-hairing of bovine pelts. The effect of temperature, initial $\mathrm{pH}$ and media composition on protease production by this keratinolytic strain was studied. The enzyme was produced between 25 and $37^{\circ} \mathrm{C}$, with maximum activity and yield at $30^{\circ} \mathrm{C}$. When protease production was tested in media with different initial pH, maximum activity was observed when cultivation was carried out at $30^{\circ} \mathrm{C}$ and initial $\mathrm{pH}$ ranging from 6.0 to 8.0. Higher activity was observed when feathers or feather meal were used as growth substrates, followed by soybean meal. The addition of carbohydrates or surfactants to feather broth resulted in decrease in keratinolytic activity.

Proteolytic enzymes are largely used in the industry for biotechnological applications involving the hydrolysis of protein substrates. Proteases constitute an important fraction of the global enzyme sales, and a relevant part of this market is accounted by bacterial proteases (Rao et al. 1998). Bacterial keratinases are of particular interest because of their action on insoluble keratin substrates, and generally on a broad range of protein substrates (Lin et al. 1995). These enzymes have been studied for de-hairing processes in the leather industry (Raju et al. 1996) and hydrolysis of feather keratin (Lin et al. 1995), which is a by-product generated in huge amounts by the poultry industry. Discarded feathers are currently used to produce feather meal through thermal processing, resulting in a low nutritional value product (Wang and Parsons, 1997). Feather hydrolysates produced by bacterial keratinases have been used as additives for animal feed (Williams et al. 1991). In addition, keratin hydrolysates have potential use as organic fertilizers, production of edible films and rare amino acids (Dalev and Neitchev, 1991; Choi and Nelson, 1996).

Cultivation conditions are essential in successful production of an enzyme, and optimization of parameters such as $\mathrm{pH}$, temperature and media composition is important in developing the cultivation process. Despite all the work that has been done on production of proteolytic enzymes, relatively little information is available on keratinases (Wang and Shih, 1999). This is even more the case for keratinases of Gram-negative bacteria (Sangali and Brandelli, 2000). The Chryseobacterium sp. strain kr6 was isolated from waste of a poultry industry and was capable to completely degrade chicken feathers. Its extracellular keratinase is a metalloprotease with great potential for biotechnological applications (Riffel et al. 2003a). This work describes the effect of temperature, initial $\mathrm{pH}$ and substrates on keratinase production by Chryseobacterium sp. kr6 during growth on native feathers.

\section{MATERIALS AND METHODS}

\section{Bacterial strain and media}

The bacterium Chryseobacterium sp. strain kr6 (LBM 9006) was isolated and characterized as described by Riffel

*Corresponding author 
et al. (2003a). Brain heart infusion broth (BHI, Difco) medium was used for maintenance of strain with $20 \%(\mathrm{v} / \mathrm{v})$ glycerol at $-20^{\circ} \mathrm{C}$.

\section{Enzyme activity and protein determination}

The proteolytic activity was monitored as describe previously (Sangali and Brandelli, 2000). Briefly, $100 \mu \mathrm{l}$ of enzyme extract was added to $400 \mu \mathrm{l}$ of $10 \mathrm{mg} \mathrm{ml}^{-1}$ azokeratin in $0.1 \mathrm{M}$ phosphate $\mathrm{pH}$ 8.0. The reaction mixture was incubated for $15 \mathrm{~min}$ at $50^{\circ} \mathrm{C}$ and then stopped by addition of trichloroacetic acid to reach a final concentration of $10 \%(\mathrm{w} / \mathrm{v})$. Absorbance at $440 \mathrm{~nm}$ was measured after centrifugation at $10,000 \mathrm{~g}$ for $5 \mathrm{~min}$. One unit of activity was the amount of enzyme that caused a change of absorbance of 0.01 at $440 \mathrm{~nm}$ in $15 \mathrm{~min}$ at $50^{\circ} \mathrm{C}$. Azokeratin was synthesized as described by Riffel et al. (2003b). The protein concentration was measured by the Folin phenol reagent method (Lowry et al. 1951).

\section{Growth conditions}

The inoculum was prepared by streaking a feather meal agar $\left(10 \mathrm{~g} \mathrm{l}^{-1}\right.$ feather meal, $15 \mathrm{~g} \mathrm{l}^{-1}$ agar, $5 \mathrm{~g} \mathrm{l}^{-1} \mathrm{NaCl}, 0.4 \mathrm{~g} \mathrm{l}^{-}$ ${ }^{1} \mathrm{Na}_{2} \mathrm{HPO}_{4}, 0.3 \mathrm{~g}^{-1} \mathrm{NaH}_{2} \mathrm{PO}_{4}$ ) plate with cells from a stock culture of kr6 strain. A single colony was transferred to 10 $\mathrm{ml}$ of feather meal broth (FMB; $10 \mathrm{~g} \mathrm{l}^{-1}$ feather meal, $5 \mathrm{~g} \mathrm{l}^{-1}$ $\mathrm{NaCl}, 0.4 \mathrm{~g} \mathrm{l}^{-1} \mathrm{Na}_{2} \mathrm{HPO}_{4}, 0.3 \mathrm{~g} \mathrm{l}^{-1} \mathrm{NaH}_{2} \mathrm{PO}_{4}$ ), incubated at $30^{\circ} \mathrm{C}$ until the cell density reached about $10^{8}$ cells $\mathrm{ml}^{-1}$. Then $1.0 \mathrm{ml}$ was transferred to $500 \mathrm{ml}$ Erlenmeyer flasks containing $100 \mathrm{ml}$ of feather keratin broth (FKB; washed, whole feathers are used instead of feather meal) and cultivated in a shaker at 180 cycles min $^{-1}$ for desired times. Bacterial growth was monitored by viable cell counts (CFU $\mathrm{ml}^{-1}$ ) and related to biomass dry weight with a calibration curve. The culture supernatants were used for assays of proteolytic activity.

The influence of temperature on growth and production of protease was studied at $25^{\circ} \mathrm{C}, 30^{\circ} \mathrm{C}, 37^{\circ} \mathrm{C}$ and $42^{\circ} \mathrm{C}$. Protease production was also investigated in FKB medium with initial $\mathrm{pH}$ adjusted to 5.0, 6.0, 7.0, 8.0 and 9.0. The cultivation was carried out at $30^{\circ} \mathrm{C}$.

When different protein sources were used as substrates, a concentration of $10 \mathrm{~g}^{-1}$ was used, replacing the raw feathers. The effect of carbohydrates on keratinase production was tested by adding $10 \mathrm{~g} \mathrm{l}^{-1}$ of glucose, sucrose or lactose to FKB. The effect of surfactants was tested by the addition of $10 \mathrm{~g} \mathrm{l}^{-1}$ of Tween 80 or Triton X-100.

All experiments were done in triplicate.

\section{Kinetic parameters}

Kinetic data were analyzed as described elsewhere (Sinclair and Cantero, 1990; Doran, 1995). The maximal specific growth rate $\left(\mu_{\max }\right)$ was calculated from the equation:

$$
\mu=\mathrm{d} X / X \mathrm{dt}
$$

where $X$ is the cell concentration in $\mathrm{gl}^{-1}$ and $\mathrm{t}$ the time (h).

Specific production rates $\left(q_{P}\right)$, defined as the amount of activity produced per gram of cell dry mass and per hour (U $\mathrm{g}^{-1} \mathrm{~h}^{-1}$ ) were calculated during growth from the relation:

$$
q p=\mathrm{d} P / X \mathrm{dt}
$$

where $\mathrm{P}$ is the activity expressed in $\mathrm{U} \mathrm{l}^{-1}, X$ the biomass concentration on $\mathrm{gl}^{-1}$ and $\mathrm{t}$ the time (h).

\section{RESULTS}

The strain of Chryseobacterium sp. kr6 grew well and completely degraded chicken feathers in the medium (Figure 1). This intense feather-degrading activity was achieved in the range of $25-37^{\circ} \mathrm{C}$ and with initial $\mathrm{pH}$ adjusted from 6.0 to 8.0. Similar growth curves were observed within this range of temperature and $\mathrm{pH}$. A typical curve is shown in Figure 2. The stationary growth phase was reached after $24 \mathrm{~h}$, coinciding with maximum proteolytic activity. In all cases, the $\mathrm{pH}$ values increased up to 8.3 during cultivation, and maximum specific production rate was achieved at $24 \mathrm{~h}$, coinciding with the end of exponential growth phase. No important growth neither proteolytic activity were observed during cultivation of the strain at $42^{\circ} \mathrm{C}$ or higher and $\mathrm{pH} 9.0$ or higher (not shown).

The maximum specific growth rate $\left(\mu_{\max }\right)$, the doubling time $\left(\mathrm{t}_{\mathrm{d}}\right)$, the yield of specific product formation $\left(Y_{\mathrm{P} / \mathrm{X}}\right)$, and specific production rate $\left(q_{p}\right)$, calculated at the final growth phase are shown in Table 1. Maximum enzyme activity and enzyme yields were observed at $30^{\circ} \mathrm{C}$ and $\mathrm{pH}$ ranging from 6.0 to 7.0. Maximum biomass was obtained with more alkaline $\mathrm{pH}$ values (Table 1). Although the production pattern of keratinase was similar for the different $\mathrm{pH}$ values tested, lower activities were observed at $\mathrm{pH}$ 5.0. The $q_{p}$ values were higher at $30^{\circ} \mathrm{C}$ and $\mathrm{pH} 6.0-7.0$.

The effect of various substrates on keratinase production was investigated. Production of keratinase activity was similar when the strain kr6 was grown in raw feathers or feather meal, but decreased with other proteinaceous substrates (Figure 3). The FKB medium was supplemented with carbohydrates and the production of keratinase was then evaluated. The addition of glucose, and markedly sucrose or lactose, resulted in strong inhibition of keratinase synthesis (Figure 3). Other additives such as the surfactants Tween 80 and Triton X-100 also caused reduction in protease yields of about $90 \%$ and $75 \%$, respectively.

The effect of concentration of three growth substrates on keratinase production was tested. Keratinase was produced at a similar level at different concentration of raw feathers and feather meal (Figure 4). Increased amounts of feather and feather meal resulted in higher bacterial growth, but the cultivation with $50 \mathrm{~g} \mathrm{l}^{-1}$ feathers resulted in a share of fragmented quills in solution. When soy meal was used as substrate, a decrease in keratinase activity was observed at 
elevated concentrations, although this effect was less evident at longer cultivation times (Figure 4).

The yields for the production of keratinase using three inexpensive common substrates were determined (Table 2). The most effective production was achieved by using feather meal, which is 1.6 fold higher than that in soy meal.

\section{DISCUSSION}

A keratinase was produced by Chryseobacterium sp. kr6 under different growth conditions. This enzyme has been shown to be useful for biotechnological purposes such as hydrolysis of poultry feathers (Riffel et al. 2003a) and dehairing of bovine pelts (Riffel et al. 2003b).

Proteases from Chryseobacterium strains are often produced at mesophilic temperatures. A metalloprotease of $C$. indologenes Ix9a (Venter et al. 1999) and an endopeptidase of Chryseobacterium sp. (Lijnen et al. 2000) were produced during cultivation in nutrient broth at $25^{\circ} \mathrm{C}$ and $28^{\circ} \mathrm{C}$, respectively. Although those conditions were considered satisfactory to produce proteolytic activity, other settings were not investigated. In the current work, biomass and enzyme activity were found to be higher at 25$30^{\circ} \mathrm{C}$ than $37^{\circ} \mathrm{C}$ (Table 1). Although keratinolytic bacteria often display optimal growth and activity at higher temperatures (Lin et al. 1999; Kim et al. 2001), this is consistent with optimum values described for keratinolytic gram-negatives such as Vibrio sp. kr2 (Sangali and Brandelli, 2000), Lysobacter sp. (Allpress et al. 2002) and Stenotrophomonas sp. D-1 (Yamamura et al. 2002), which showed optimum temperature for growth and keratinolytic enzyme production ranging from $20^{\circ} \mathrm{C}$ to $30^{\circ} \mathrm{C}$.

Maximum biomass and keratinase activity were observed from $\mathrm{pH} 6.0$ to 8.0 (Table 1), which agrees with those described for most feather-degrading Bacillus (Wang and Shih, 1999; Suntornsukz and Sutornsukz, 2003). For production of keratinase by $B$. licheniformis and a recombinant $B$. subtilis, uncontrolled $\mathrm{pH}$ operation was more favorable than the controlled $\mathrm{pH}$ operations (Wang and Shih, 1999). The same was observed for alkaline protease production by $B$. licheniformis (Çalik et al. 2002).

Maximum activities were coinciding with maximum biomass and maximum specific production rates were observed at the exponential growth phase, suggesting that the keratinase of strain kr6 was produced as a primary metabolite (Figure 2).

Carbohydrate inhibition of keratinase production was observed (Figure 3), indicating that this strain has a catabolite repression regulatory mechanism, a common control mechanism for biosynthesis of bacterial proteases (Givskov et al. 1991), including keratinases (Wang and Shih, 1999; Thys et al. 2004). Suitable amounts of some surfactants, such as Tween 80 and Triton X-100, are known to stimulate bacterial enzyme production (Reddy et al.
1999). However, the addition of these detergents into the FKB suppressed bacterial growth and keratinase production (Figure 3), similar to that observed for Bacillus sp. FK46 during submerged cultivation (Suntornsukz and Sutornsukz, 2003).

Although the production of proteases in complex growth media often promotes exuberant growth and high enzyme yields (Johnvesly and Naik, 2001; Joo et al. 2002), their expensive cost makes them unsuitable for a large-scale production. Some less expensive substrates, such as soybean meal, have been successfully used (Wang and Shih, 1999; Joo et al. 2002). It seems more adequate to use raw materials like some wastes from the food industry as a basis of the culture media. The strain kr6 produced higher yields in feather meal and raw feathers, which have been used as good substrates for production of other keratinolytic enzymes (Wang and Shih, 1999; Sangali and Brandelli, 2000).

High substrate concentrations may cause substrate inhibition or repression of keratinase production. This was observed when soy meal was used as substrate, similar to that described by Joo et al. (2002) during protease production by Bacillus horikoshii. This indicates that smaller amounts of substrate are preferred since they result in higher yields of product per substrate $\left(\mathrm{U} \mathrm{g}^{-1}\right.$ substrate). It was previously observed for the strain kr6 that substrate and metabolite levels in the extracellular milieu can regulate enzyme secretion (Riffel et al. 2003a). As the strain grows in soy meal faster than in feather substrates, different kinetics for keratinase production would be expected, depending on the type and amount of substrate.

Keratinases have enormous potential applications in processing waste in the poultry and leather industries. The recent finding that B. licheniformis PWD-1 keratinase cause enzymatic breakdown of prion protein $\mathrm{PrP}^{\mathrm{Sc}}$ (Langeveld et al. 2003) leave open a novel relevant application for broad range keratinases. In this study, the optimum conditions for keratinase synthesis by the Chryseobacterium strain kr6 were determined, which is an essential step for the production of adequate amounts for application in research of feed and other areas.

\section{REFERENCES}

ALLPRESS, J.D.; MOUNTAIN, G. and GOWLAND, P.C. Production, purification and characterization of an extracellular keratinase from Lysobacter NCIMB 9497. Letters in Applied Microbiology, May 2002, vol. 34, no. 5, p. 337-342.

ÇALIK, P.; BILIR, E.; ÇALIK, G. and ÖZDAMAR, T.H. Influence of $\mathrm{pH}$ conditions on metabolic regulations in serine alkaline protease production by Bacillus licheniformis. Enzyme and Microbial Technology, October 2002, vol. 31, no. 5, p. 685-697. 
CHOI, J.M. and NELSON, P.V. Developing a slow-release nitrogen fertilizer from organic sources. 2. Using poultry feathers. Journal of the American Society of Horticultural Science, July 1996, vol. 121, no. 4, p. 634-638.

DALEV, P. and NEITCHEV, V. Reactivity of alkaline proteinase to keratin and collagen containing substances. Applied Biochemistry and Biotechnology, February 1991, vol. 27, no. 2, p. 131-138.

DORAN, P.M. Bioprocess Engineering Principles. San Diego, Academic Press, 1995. 439 p. ISBN 0-12-220856-0.

GIVSKOV, M.; EBERL, L. and MOLIN, S. Control of exoenzyme production, motility and cell differentiation in Serratia liquefaciens. FEMS Microbiology Letters, March 1991, vol. 148, no. 2, p. 115-122.

JOHNVESLY, B. and NAIK, G.R. Studies on production of thermostable alkaline protease from thermophilic and alkaliphilic Bacillus sp. JB-99 in a chemically defined medium. Process Biochemistry, October 2001, vol. 37, no. 2, p. 139-144.

JOO, H.S.; KUMAR, C.G.; PARK, G.C.; KIM, K.T.; PAIK, S.R. and CHANG, C.S. Optimization of the production of an extracellular alkaline protease from Bacillus hirikoshii. Process Biochemistry, October 2002, vol. 38, no. 2, p. 155-159.

KIM, J.M.; LIM, W.J. and SUH, H.J. Feather-degrading Bacillus species from poultry waste. Process Biochemistry, November 2001, vol. 37, no. 3, p. 287-291.

LANGEVELD, J.P.M.; WANG, J.J.; VAN DE WIEL, D.F.M.; SHIH, G.C.; GARSSEN, J.; BOSSERS, A. and SHIH, J.C.H. Enzymatic degradation of prion protein in brain stem from infected cattle and sheep. Journal of Infectious Diseases, December 2003, vol. 188, no. 11, p. 1782-1789.

LIJNEN, H.R.; VAN HOEF, B.; UGWU, F.; COLLEN, D. and ROELANTS, I. Specific hydrolysis of human plasminogen by a $24 \mathrm{kDa}$ endopeptidase from a novel Chryseobacterium sp. Biochemistry, January 2000, vol. 39, no. 2, p. 479-488.

LIN, X.; INGLIS, G.D.; YANKE, L.J. and CHENG, K.J. Selection and characterization of feather-degrading bacteria from canola meal compost. Journal of Industrial Microbiology and Biotechnology, August 1999, vol. 23, no. 2, p. 149-153.

LIN, X.; LEE, C.G.; CASALE, E.S. and SHIH, J.C.H. Purification and characterization of a keratinase from a feather-degrading Bacillus licheniformis strain. Applied and Environmental Microbiology, October 1995, vol. 58, no. 10, p. 3271-3275.
LOWRY, O.H.; ROSEMBROUGH, N.J.; FARR, A.L. and RANDALL, R.J. Protein measurement with the Folin phenol reagent. Journal of Biological Chemistry, January 1951, vol. 193, no. 1, p. 267-275.

RAJU, A.A.; CHANDRABABU, N.K.; SAMIVELU, N., ROSE, C. and RAO, N.M. Eco-friendly enzymatic dehairing using extracellular proteases from a Bacillus species isolate. Journal of the American Leather Chemical Association, May 1996, vol. 91, no. 5, p. 115-119.

RAO, M.B.; TANKSALE, A.M.; GHATGE, M.S. and DESHPANDE, V.V. Molecular and biotechnological aspects of microbial proteases. Microbiology and Molecular Biology Reviews, September 1998, vol. 62, no. 3, p. 597-635.

REDDY, R.M.; REDDY, P.G. and SEENAYYA, G. Enhanced production of thermostable $\beta$-amylase and pullanase in the presence of surfactants by Clostridium thermosulfurogenes SV2. Process Biochemistry, January 1999, vol. 34, no. 1, p. 87-92.

RIFFEL, A.; LUCAS, F.S.; HEEB, P. and BRANDELLI, A. Characterization of a new keratinolytic bacterium that completely degrades native feather keratin. Archives of Microbiology, April 2003a, vol. 179, no. 4, p. 258-265.

RIFFEL, A.; ORTOLAN, S. and BRANDELLI, A. Dehairing activity of extracellular proteases produced by keratinolytic bacteria. Journal of Chemical Technology and Biotechnology, August 2003b, vol. 78, no. 8, p. 855-859.

SANGALI, S. and BRANDELLI, A. Feather keratin hydrolysis by a Vibrio sp. strain kr2. Journal of Applied Microbiology, November 2000, vol. 89, no. 5, p. 735-743.

SINCLAIR, C.G. and CANTERO, D. Fermentation modeling. In: McNEIL, B. and HARVEY, L.M. eds. Fermentations, a practical approach. Oxford, IRL Press, 1990, p. 65-113. ISBN 0199630453.

SUNTORNSUK, W. and SUNTORNSUK, L. Feather degradation by Bacillus sp. FK46 in submerged cultivation. Bioresource Technology, February 2003, vol. 86, no. 3, p. 239-243.

THYS, R.C.S.; LUCAS, F.S.; RIFFEL, A.; HEEB, P. and BRANDELLI, A. Characterization of a protease of a feather-degrading Microbacterium species. Letters in Applied Microbiology, February 2004, vol. 39, no. 2, p. 181-186.

VENTER, H.; OSTHOFF, G. and LITTHAUER, D. Purification and characterization of a metalloprotease from Chyseobacterium indologenes Ix9a and determination of the amino acid specificity with electrospray mass spectrometry. Protein Expression and Purification, April 1999, vol. 15, no. 3, p. 282-295. 
WANG, J.J. and SHIH, J.C.H. Fermentation production of keratinase from Bacillus licheniformis PWD-1 and a recombinant $B$. subtilis FDB-29. Journal of Industrial Microbiology and Biotechnology, June 1999, vol. 22, no. 6, p. 608-616.

WANG, X. and PARSONS, C.M. Effect of processing systems on protein quality of feather meal and hog hair meals. Poultry Science, March 1997, vol. 76, no. 3, p. 491496.

WILLIAMS, C.M.; LEE, C.G.; GARLICH, J.D. and SHIH, J.C.H. Evaluation of a bacterial feather fermentation product, feather-lysate, as a feed protein. Poultry Science, January 1991, vol. 70, no. 1, p. 85-94.

YAMAMURA, S.; MORITA, Y.; HASAN, Q.; RAO, S.R.; MARAKAMI,Y.; YOKOYAMA, K. and TAMIYA, E. Characterization of a new keratin-degrading bacterium isolated from deer fur. Journal of Bioscience and Bioengineering, June 2002, vol. 93, no. 6, p. 595-600. 


\section{APPENDIX}

\section{Tables}

Table 1. Kinetic constants of growth and protease production during cultivation of Chryseobacterium sp. kr6 in feather keratin broth.

\begin{tabular}{|l|c|c|c|c|c|c|}
\hline \multicolumn{7}{|c|}{$T\left({ }^{\circ} \mathrm{C}\right) /$ initial pH } \\
\hline Parameter & $25 / 6.0$ & $30 / 6.0$ & $37 / 6.0$ & $30 / 5.0$ & $30 / 7.0$ & $30 / 8.0$ \\
\hline$\mu_{\max }\left(\mathrm{h}^{-1}\right)$ & 0.020 & 0.037 & 0.016 & 0.033 & 0.032 & 0.033 \\
\hline $\mathrm{t}_{\mathrm{d}}(\mathrm{h})$ & 34.6 & 18.7 & 43.3 & 21.0 & 21.7 & 21.0 \\
\hline $\mathrm{X}_{\max }\left(\mathrm{g} \mathrm{I}^{-1}\right)^{\mathrm{a}}$ & 0.36 & 0.35 & 0.29 & 0.38 & 0.39 & 0.41 \\
\hline $\mathrm{A}_{\max }\left(\mathrm{U} \mathrm{ml}^{-1}\right)^{\mathrm{a}}$ & 60 & 88 & 42 & 57 & 86 & 82 \\
\hline $\left.\mathrm{Y}_{\mathrm{P} / \mathrm{X}}(\mathrm{U} \mathrm{mg})^{-1}\right)$ & 167 & 231 & 145 & 150 & 221 & 191 \\
\hline $\mathrm{q}_{\mathrm{p}}\left(\mathrm{U} \mathrm{mg}{ }^{-1} \mathrm{~h}^{-1}\right)$ & 6.94 & 10.5 & 6.03 & 6.25 & 9.18 & 8.33 \\
\hline
\end{tabular}

${ }^{a}$ Values are the means of three determinations.

Table 2. Estimation of keratinase yields with different substrates.

\begin{tabular}{|l|c|c|c|}
\hline & Raw feathers & Feather meal & Soy meal \\
\hline Activity $\left(\mathrm{U} \mathrm{ml}^{-1}\right)$ & 82 & 95 & 60 \\
\hline Cell yield $\left(\mathrm{g} \mathrm{g}^{-1}\right.$ substrate) & 0.04 & 0.05 & 0.07 \\
\hline Keratinase yield $\left(\mathrm{U} \mathrm{g}^{-1}\right.$ substrate $)$ & 8600 & 9500 & 6000 \\
\hline
\end{tabular}




\section{Figures}

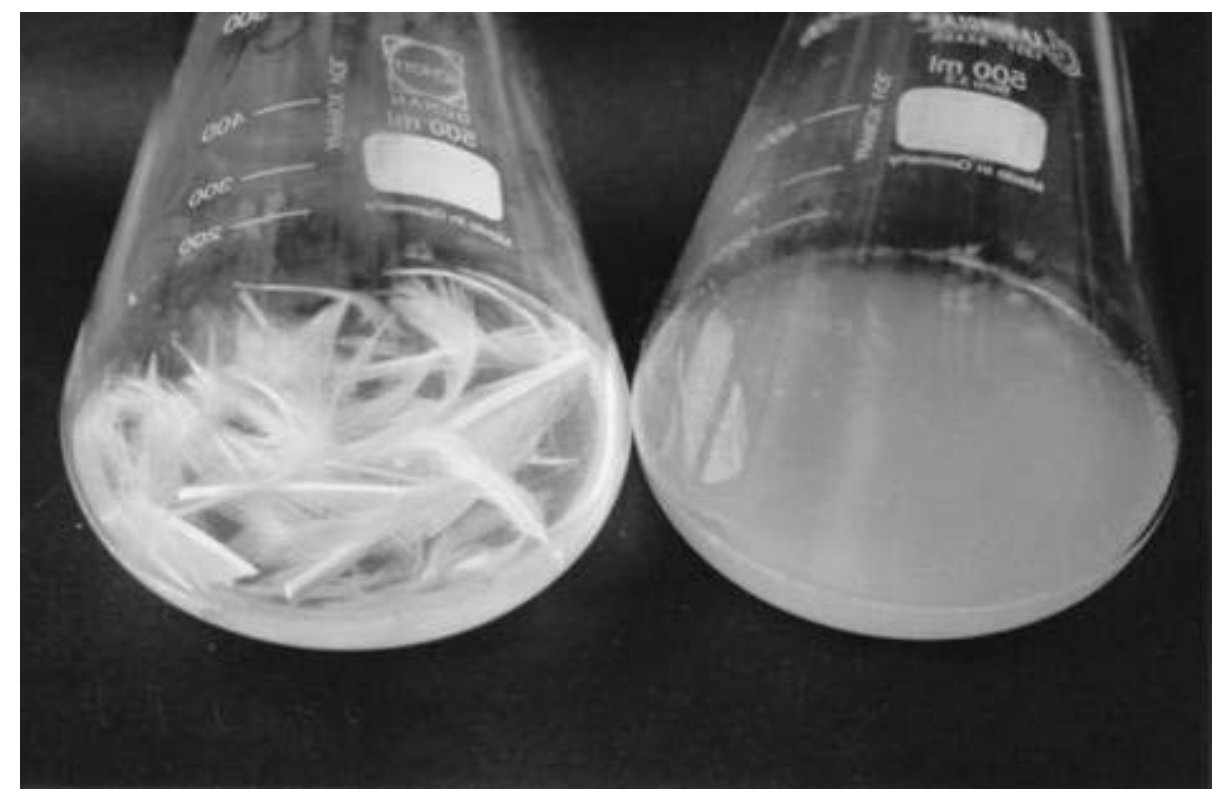

Figure 1. Feather degradation by Chryseobacterium sp. kr6. Feathers were incubated for $48 \mathrm{hrs}$ at $30^{\circ} \mathrm{C}$ with viable cells of the strain kr6 (right flask) and with autoclaved inoculum as control (left flask).

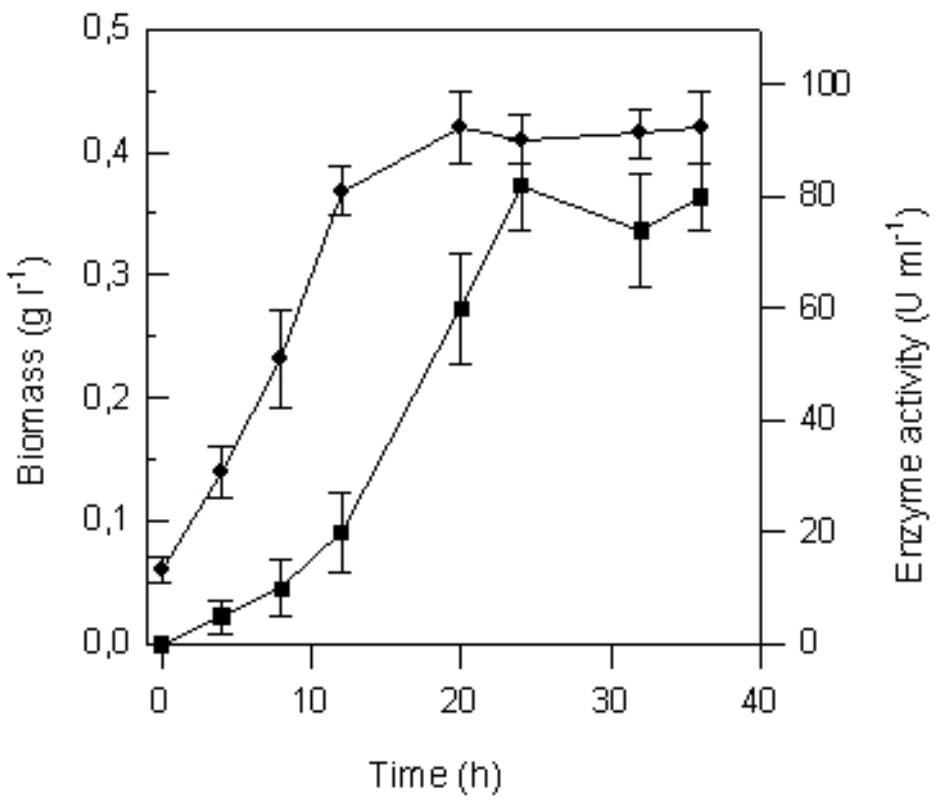

Figure 2. Keratinase activity (squares) during growth (circles) of strain kr6 on $10 \mathrm{~g} \mathrm{l}^{-1}$ raw feathers at $30^{\circ} \mathrm{C}$ and initial pH 7.0. Points are the means \pm s.e.m. of three independent experiments. 


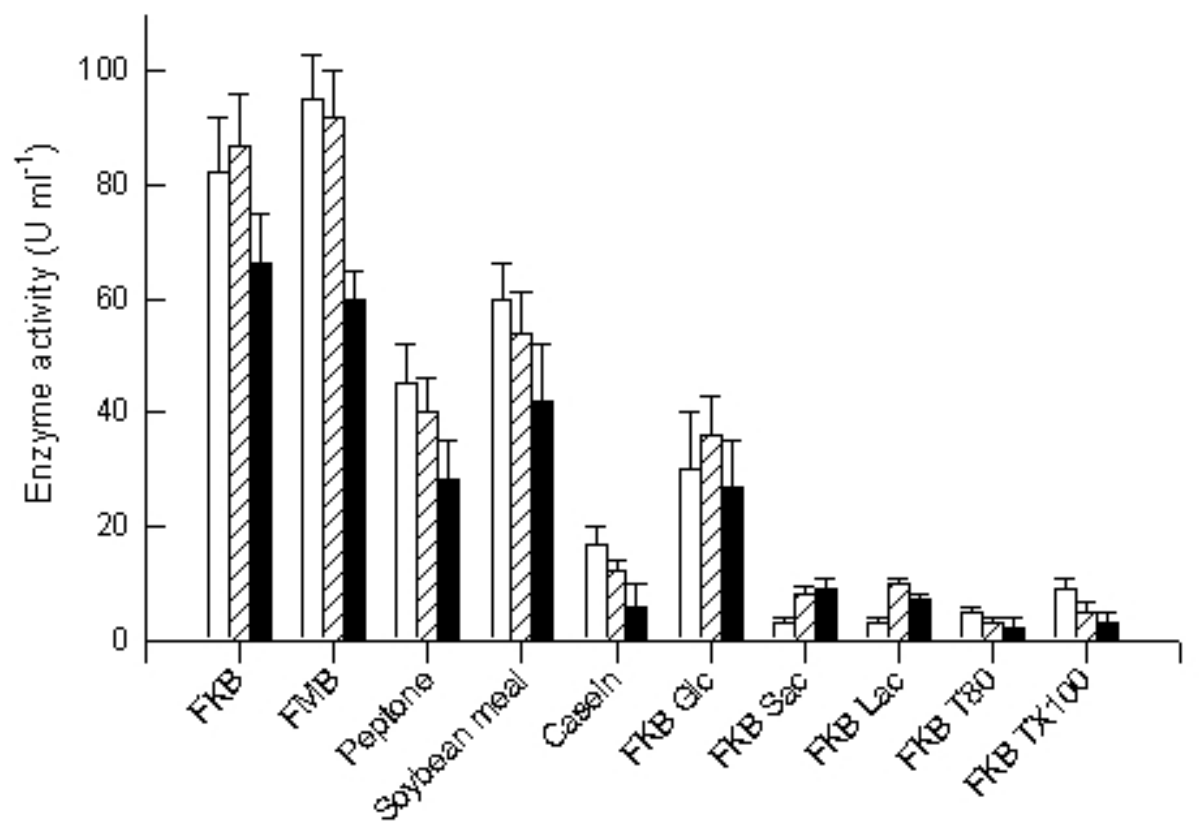

Figure 3. Effect of growth substrates on protease production by Chryseobacterium sp. kr6 at $30^{\circ} \mathrm{C}$ and initial pH 7.0 after 24 hrs (white bars), 48 hrs (dashed bars) and 72 hrs (black bars) cultivation. Bars are the means \pm s.e.m. of three independent experiments. FKB, feather keratin broth; FMB, feather meal broth; Glc, Sac, Lac, T80, TX100 indicate the FKB contained $10 \mathrm{~g} \mathrm{l}^{-1}$ of glucose, sucrose, lactose, Tween 80 or Triton X100 , respectively.

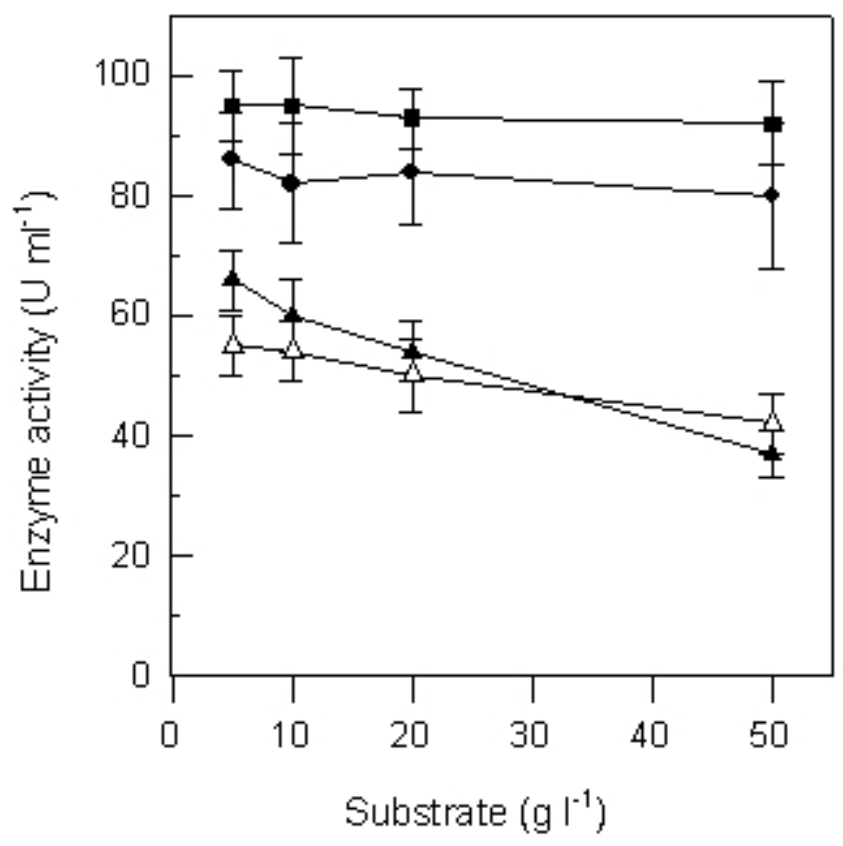

Figure 4. Effect of growth substrate concentration on protease production by Chryseobacterium sp. $\mathrm{kr} 6$ at $30^{\circ} \mathrm{C}$ and initial $\mathrm{pH} 7.0$ in media containing different amounts of raw feathers (circles), feather meal (squares) or soy meal (triangles) after 24 hrs (black symbols) and 48 hrs (white symbols) cultivation. Points are the means \pm s.e.m. of three independent experiments. 